\title{
No association between TP53 Arg72Pro polymorphism and ovarian cancer risk: evidence from 10113 subjects
}

\author{
Anqi Zhang ${ }^{1, *}$, Ting-Yan Shi ${ }^{2, *}$, Yuan Zhao ${ }^{1}$, Junmiao Xiang ${ }^{1}$, Danyang $\mathbf{Y u}^{1}$, Zongwen \\ Liang ${ }^{1}$, Chaoyi Xu' ${ }^{1}$, Qiong Zhang ${ }^{1}$, Yue Hu ${ }^{1}$, Danhan Wang ${ }^{1}$, Jing $\mathrm{He}^{1,3}$ and Ping Duan ${ }^{1}$ \\ ${ }^{1}$ Department of Obstetrics and Gynecology, The Second Affiliated Hospital and Yuying Children's Hospital of Wenzhou Medical \\ University, Wenzhou 325027, Zhejiang, China \\ ${ }^{2}$ Department of Obstetrics and Gynecology, Zhongshan Hospital, Fudan University, Shanghai 200032, China \\ ${ }^{3}$ Department of Pediatric Surgery, Guangzhou Institute of Pediatrics, Guangzhou Women and Children's Medical Center, \\ Guangzhou Medical University, Guangzhou 510623, Guangdong, China \\ *These authors have contributed equally to this work \\ Correspondence to: Ping Duan, email: dppddpp@126.com \\ Jing He, email: hejing198374@gmail.com \\ Keywords: TP53; polymorphism; ovarian cancer; susceptibility; meta-analysis \\ Received: June 10,2017 Accepted: November 04, $2017 \quad$ Published: November 21, 2017 \\ Copyright: Zhang et al. This is an open-access article distributed under the terms of the Creative Commons Attribution License 3.0 \\ (CC BY 3.0), which permits unrestricted use, distribution, and reproduction in any medium, provided the original author and source \\ are credited.
}

\section{ABSTRACT}

The TP53 gene product is an important regulator of cell growth and a tumor suppressor. The association between TP53 Arg72Pro polymorphism and ovarian cancer risk has been widely investigated, but the results are contradictory. We therefore searched the PubMed, EMBASE and Chinese Biomedical databases for studies on the relation between TP53 Arg72Pro polymorphism and ovarian cancer risk. Our final meta-analysis included 24 published studies with 3271 cases and 6842 controls. Pooled results indicated that there was no significant association between TP53 Arg72Pro polymorphism and ovarian cancer risk [Pro/Pro vs. Arg/Arg: odds ratio $(O R)=1.04,95 \%$ confidence interval $(\mathrm{CI})=0.81-1.34 ;$ Arg/Pro vs. Arg/Arg: OR = $1.14,95 \% \mathrm{CI}=0.96-1.36$; recessive: $\mathrm{OR}=1.05,95 \% \mathrm{CI}=0.90-1.22$; dominant: $\mathrm{OR}=$ $1.12,95 \% \mathrm{CI}=0.94-1.33$; and Pro vs. $\mathrm{Arg}$ : $\mathrm{OR}=1.06,95 \% \mathrm{CI}=0.93-1.20]$. Likewise, stratified analyses failed to reveal a genetic association. Despite some limitations, the present meta-analysis provides statistical evidence indicating a lack of association between TP53 Arg72Pro polymorphism and ovarian cancer risk.

\section{INTRODUCTION}

With 238,700 new cases worldwide, ovarian cancer was the seventh most frequently occurring cancer among women in 2012, and was responsible for 151,900 deaths. In developing countries, newly diagnosed cases of ovarian cancer have exceeded those of cervical cancer [1]. Moreover, mortality from ovarian cancer has decreased by only 1.29 per 100,000 over the past several decades due in large part to the paucity of effective screening methods and chemopreventive agents, and to its being asymptomatic during early stages $[2,3]$. Although active surgical treatment and adjuvant chemotherapy have been applied to the treatment of advanced ovarian cancer, the prognosis of the patients remains poor with a 5 -year survival rate of only $23 \%[4,5]$. Considerable research has focused on explaining the molecular mechanisms underlying ovarian cancer, but in the absence of an appropriate progression model, they remain far from clear $[6,7]$. Thus, identification of a sensitive and early-detected biomarker useful for cancer prediction and prevention is badly needed.

TP53 is a tumor suppressor gene is located on the chromosome $17 \mathrm{p} 13$ short arm and encodes a protein with 393 amino acids [8]. Its product, p53, is regarded as a major inhibitor of tumorigenesis, which is involved in cycle arrest, DNA repair, apoptosis or cellular aging $[9,10]$. Mutations in TP53 can result in Li-Fraumeni syndrome, which increases the risk of diverse cancers, including breast cancer, carcinosarcoma, leukemia and 
brain tumors, among others [11]. In addition to the tumorassociated TP53 mutations, polymorphisms also have an important impact on the susceptibility to cancer [12-15]. The well-studied TP53 polymorphism is at codon 72 of exon 4 (CGC to CCC) and corresponds to a change from arginine to proline $[16,17]$. The two polymorphic forms of TP53 exhibit differences in their biological function. Whereas the Arg72 form induces cell apoptosis upon stress and inhibits tumorigenesis, the Pro72 inhibits the G1 phase of cell cycle progression [18]. There has been much research on the relationship between TP53 codon 72 polymorphism and ovarian cancer risk, but the results are conflicting and inconsistent. Some studies have shown that the TP53 Arg allele is associated with a higher risk of ovarian cancers [19-21], while others found that the TP53 Pro allele is likely a risk factor for ovarian cancer [22-24]. In addition, there are also publications suggesting the TP53 Arg72Pro polymorphism is not associated with susceptibility to ovarian cancer $[25,26]$. The reasons for the contradictory results may be attributable to inadequate sample size, different sources of DNA, ethnicity, different environmental exposures, or the borderline effect of genetic variant. In an effort to increase clarity, we collected all eligible studies and analyzed the potential effect of TP53 codon 72 polymorphism on the susceptibility to ovarian cancer.

\section{RESULTS}

\section{Study characteristics}

Through searches of the PubMed, EMBASE and Chinese Biomedical (CBM) databases, a total of 424 potentially relevant articles were initially identified. Of those, 386 were excluded, and 38 were chosen for further evaluation through checking of the title and abstract (Figure 1). Based on the inclusion criteria described below in the Methods, 18 articles were included in the final analysis [19, 20, 22-36]. Among those 18, the publication by Schildkraut et al. [26] investigated the genotype distributions of the TP53 Arg72Pro polymorphism in different areas, so it was divided into seven separate studies. Overall, 24 case-control studies with 3271 cases (13 to 626 per study) and 6842 controls (13 to 1045 per study) were included in the present meta-analysis. The main characteristics of all the included studies are presented in Table 1. Among these studies, 19 were conducted with Caucasians, four with Asians, and only one with Africans. Because detailed information about the source of the controls were not been provided in the study by Peller et al. [36], only 12 articles were classified as population-based, and 11 were hospital-based. In addition, 15 studies with a quality score $\geq 9$ were considered to be

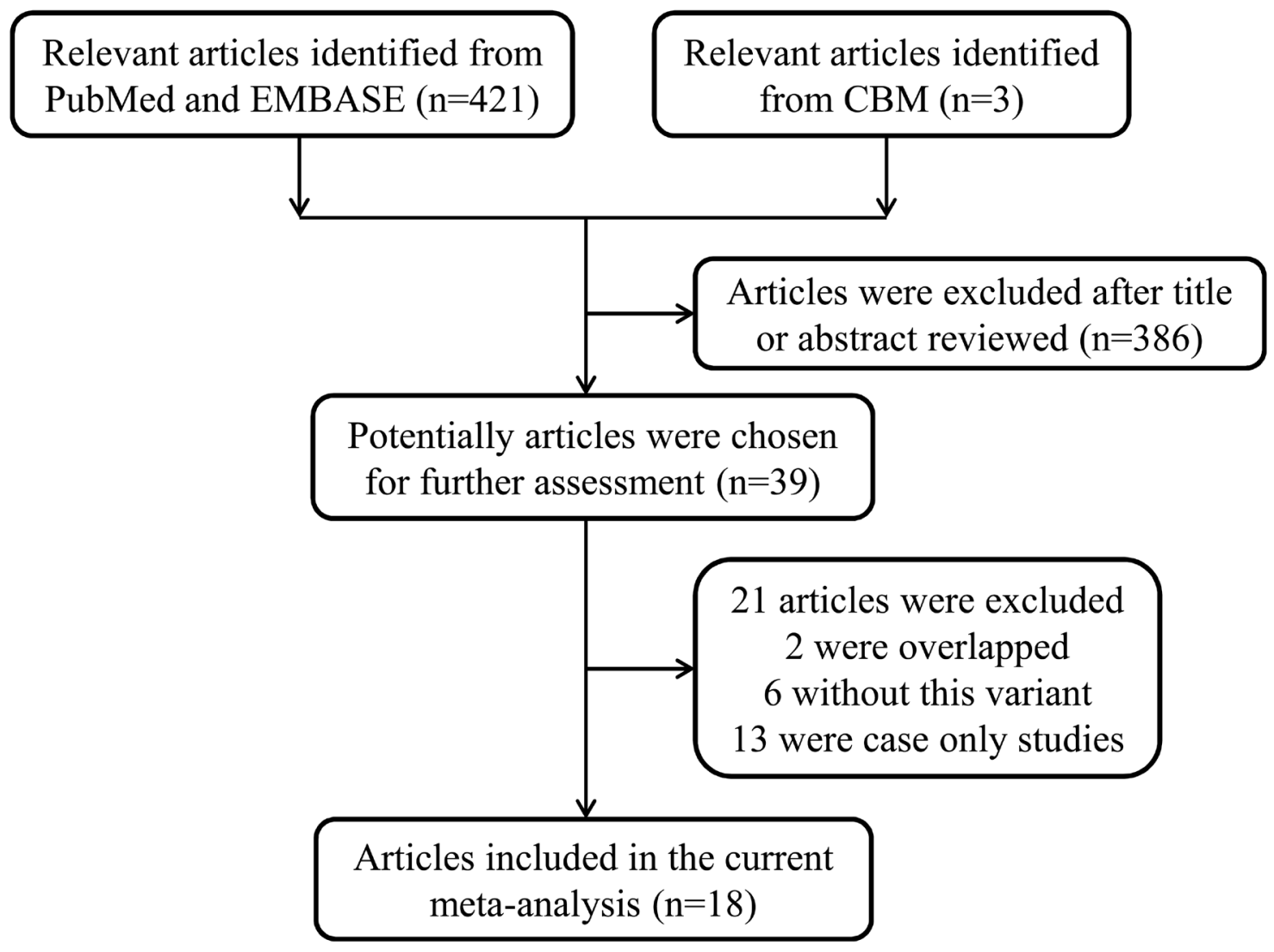

Figure 1: Flowchart of included studies. 
Table 1: Characteristics of studies included in the current meta-analysis

\begin{tabular}{|c|c|c|c|c|c|c|c|c|c|c|c|c|c|c|c|c|}
\hline \multirow{2}{*}{ Surname } & \multirow{2}{*}{ Year } & \multirow{2}{*}{ Country } & \multirow{2}{*}{ Ethnicity } & \multirow{2}{*}{ Design } & \multirow{2}{*}{$\begin{array}{c}\text { Genotyping } \\
\text { method }\end{array}$} & \multicolumn{4}{|c|}{ Case } & \multicolumn{4}{|c|}{ Control } & \multirow{2}{*}{ MAF } & \multirow{2}{*}{ HWE } & \multirow{2}{*}{ Score } \\
\hline & & & & & & $\mathbf{A A}$ & $\mathbf{A P}$ & PP & All & $\mathbf{A A}$ & $\mathbf{A P}$ & $\mathbf{P P}$ & All & & & \\
\hline Buller & 1997 & USA & Caucasian & PB & PCR-SSCP & 98 & 79 & 13 & 190 & 30 & 18 & 4 & 52 & 0.25 & 0.579 & 10 \\
\hline Peller & 1999 & Israel & Caucasian & Not detailed & DS & 7 & 6 & 0 & 13 & 8 & 5 & 0 & 13 & 0.19 & 0.447 & 5 \\
\hline Hogdall & 2002 & Denmark & Caucasian & PB & PCR-RFLP & 118 & 73 & 20 & 211 & 48 & 27 & 8 & 83 & 0.26 & 0.165 & 9 \\
\hline $\mathrm{Li}$ & 2002 & China & Asian & $\mathrm{PB}$ & PCR-RFLP & 14 & 20 & 5 & 39 & 29 & 67 & 35 & 131 & 0.52 & 0.920 & 10 \\
\hline Qie & 2002 & China & Asian & $\mathrm{HB}$ & PCR-RFLP & 10 & 18 & 2 & 30 & 12 & 16 & 2 & 30 & 0.33 & 0.273 & 5 \\
\hline Pegoraro & 2003 & $\begin{array}{l}\text { South } \\
\text { Africa }\end{array}$ & African & $\mathrm{HB}$ & AS-PCR & 9 & 29 & 25 & 63 & 32 & 147 & 161 & 340 & 0.69 & 0.852 & 6 \\
\hline Agorastos & 2004 & Greece & Caucasian & $\mathrm{HB}$ & PCR & 26 & 22 & 3 & 51 & 6 & 19 & 5 & 30 & 0.48 & 0.142 & 5 \\
\hline Kang & 2004 & China & Asian & $\mathrm{HB}$ & PCR & 28 & 60 & 36 & 124 & 37 & 64 & 27 & 128 & 0.46 & 0.945 & 9 \\
\hline Morari & 2006 & Brazil & Caucasian & PB & AS-PCR & 23 & 46 & 0 & 69 & 117 & 91 & 14 & 222 & 0.27 & 0.505 & 9 \\
\hline Santos & 2006 & Portugal & Caucasian & HB & AS-PCR & 49 & 40 & 10 & 99 & 117 & 58 & 13 & 188 & 0.22 & 0.128 & 7 \\
\hline Ueda & 2006 & Japan & Asian & $\mathrm{HB}$ & PCR-RFLP & 21 & 41 & 6 & 68 & 34 & 54 & 7 & 95 & 0.36 & 0.021 & 6 \\
\hline $\begin{array}{l}\text { Schildkraut- } \\
\text { POCS }\end{array}$ & 2009 & Poland & Caucasian & $\mathrm{PB}$ & TaqMan & 51 & 63 & 4 & 118 & 368 & 207 & 45 & 620 & 0.24 & 0.038 & 11 \\
\hline $\begin{array}{l}\text { Schildkraut- } \\
\text { NCOCS }\end{array}$ & 2009 & USA & Caucasian & $\mathrm{PB}$ & IGGA & 132 & 104 & 16 & 252 & 231 & 182 & 24 & 437 & 0.26 & 0.122 & 13 \\
\hline $\begin{array}{l}\text { Schildkraut- } \\
\text { MAYO }\end{array}$ & 2009 & USA & Caucasian & $\mathrm{PB}$ & IGGA & 96 & 82 & 14 & 192 & 261 & 157 & 37 & 455 & 0.25 & 0.057 & 13 \\
\hline $\begin{array}{l}\text { Schildkraut- } \\
\text { AUS }\end{array}$ & 2009 & Australia & Caucasian & PB & MassARRAY & 121 & 59 & 14 & 194 & 219 & 110 & 31 & 360 & 0.24 & 0.002 & 11 \\
\hline $\begin{array}{l}\text { Schildkraut- } \\
\text { HAW }\end{array}$ & 2009 & USA & Caucasian & PB & TaqMan & 18 & 12 & 0 & 30 & 78 & 60 & 8 & 146 & 0.26 & 0.416 & 12 \\
\hline $\begin{array}{l}\text { Schildkraut- } \\
\text { MAL }\end{array}$ & 2009 & Denmark & Caucasian & PB & TaqMan & 134 & 94 & 25 & 253 & 564 & 371 & 78 & 1013 & 0.26 & 0.123 & 14 \\
\hline $\begin{array}{l}\text { Schildkraut- } \\
\text { SEA }\end{array}$ & 2009 & $\begin{array}{l}\text { New- } \\
\text { England }\end{array}$ & Caucasian & PB & TaqMan & 119 & 75 & 18 & 212 & 461 & 326 & 55 & 842 & 0.26 & 0.796 & 14 \\
\hline Matei & 2012 & Roman & Caucasian & $\mathrm{HB}$ & PCR-RFLP & 9 & 6 & 6 & 21 & 7 & 7 & 7 & 21 & 0.50 & 0.127 & 4 \\
\hline Dholariya & 2013 & $\begin{array}{l}\text { North } \\
\text { India }\end{array}$ & Caucasian & $\mathrm{HB}$ & ASO-PCR & 33 & 50 & 17 & 100 & 62 & 32 & 6 & 100 & 0.22 & 0.499 & 9 \\
\hline Malisic & 2013 & Serbia & Caucasian & $\mathrm{HB}$ & PCR-RFLP & 22 & 22 & 3 & 47 & 45 & 22 & 3 & 70 & 0.20 & 0.881 & 6 \\
\hline Medrek & 2013 & Poland & Caucasian & $\mathrm{PB}$ & TaqMan & 302 & 265 & 59 & 626 & 537 & 436 & 72 & 1045 & 0.28 & 0.191 & 12 \\
\hline Tecza & 2015 & Poland & Caucasian & $\mathrm{HB}$ & PCR-RFLP & 130 & 79 & 16 & 225 & 167 & 150 & 24 & 341 & 0.29 & 0.213 & 11 \\
\hline Benhessou & 2016 & Morocco & Caucasian & $\mathrm{HB}$ & AS-PCR & 33 & 10 & 1 & 44 & 43 & 27 & 10 & 80 & 0.29 & 0.095 & 5 \\
\hline
\end{tabular}

AA, Arg/Arg; AP, Arg/Pro; PP, Pro/Pro; MAF, minor allele frequency; HWE, Hardy-Weinberg equilibrium; PB, population based; HB, hospital based; PCR, polymerase chain reaction; PCR-RFLP, PCR-restriction fragment length polymorphism; AS-PCR, allele-specific PCR; ASO-PCR, allele specific oligonucleotide; IGGA, Illumina golden gate assay; DS, direct sequencing; PCR-SSCP, PCR-single-strand conformation polymorphism assay.

high quality, while nine with a score $<9$ were regarded as low quality. Table 1 also summarizes the distribution of genotypes, minor allele frequencies (MAFs) and the Hardy-Weinberg equilibrium (HWE) in the controls.

\section{Meta-analysis}

As shown in Table 2 and Figure 2, the overall pooled analysis indicated no significant association between TP53 Arg72Pro polymorphism and ovarian cancer risk in any of the five genetic models [homozygous: odds ratio $(\mathrm{OR})=1.04,95 \%$ confidence interval $(\mathrm{CI})=0.81-1.34$; heterozygous: $\mathrm{OR}=1.14,95 \% \mathrm{CI}=0.96-1.36$; recessive: $\mathrm{OR}=1.05,95 \% \mathrm{CI}=0.90-1.22$; dominant: $\mathrm{OR}=1.12,95 \%$ $\mathrm{CI}=0.94-1.33$ and allele comparing: $\mathrm{OR}=1.06,95 \%$ $\mathrm{CI}=0.93-1.20$ ). In addition, when we performed subgroup analyses based on ethnicity, source of controls, and quality of studies, there were again no significant results indicating a relationship between the TP53 Arg72Pro polymorphism and ovarian cancer risk. 
Table 2: Meta-analysis of the association between TP53 codon 72 (rs1042522 G>C) polymorphism and ovarian cancer risk

\begin{tabular}{|c|c|c|c|c|c|c|c|c|c|c|c|c|}
\hline \multirow{2}{*}{ Variables } & \multirow{2}{*}{$\begin{array}{l}\text { No. of } \\
\text { studies }\end{array}$} & \multirow{2}{*}{$\begin{array}{c}\text { Sample } \\
\text { size }\end{array}$} & \multicolumn{2}{|c|}{ Homozygous } & \multicolumn{2}{|c|}{ Heterozygous } & \multicolumn{2}{|l|}{ Recessive } & \multicolumn{2}{|l|}{ Dominant } & \multicolumn{2}{|l|}{ Allele } \\
\hline & & & OR $(95 \%$ CI) & $P^{\text {het }}$ & OR $(95 \%$ CI) & $P$ het & OR $(95 \% \mathrm{CI})$ & $P^{\text {het }}$ & OR $(95 \% \mathrm{CI})$ & $P^{\text {het }}$ & OR $(95 \%$ CI) & $P^{\text {het }}$ \\
\hline All & 24 & $3271 / 6842$ & $1.04(0.81-1.34)$ & 0.015 & $1.14(0.96-1.36)$ & $<0.001$ & $1.05(0.90-1.22)$ & 0.131 & $1.12(0.94-1.33)$ & $<0.001$ & $1.06(0.93-1.20)$ & $<0.001$ \\
\hline \multicolumn{13}{|l|}{ Ethnicity } \\
\hline Caucasians & 19 & $2947 / 6118$ & $1.09(0.84-1.43)$ & 0.035 & $1.18(0.97-1.43)$ & $<0.001$ & $1.09(0.91-1.29)$ & 0.177 & $1.15(0.95-1.39)$ & $<0.001$ & $1.09(0.95-1.25)$ & $<0.001$ \\
\hline Asians & 4 & $261 / 384$ & $0.99(0.40-2.42)$ & 0.070 & $1.08(0.75-1.56)$ & 0.508 & $1.07(0.70-1.65)$ & 0.166 & $1.06(0.67-1.68)$ & 0.190 & $1.02(0.69-1.49)$ & 0.062 \\
\hline Africans & 1 & $63 / 340$ & $0.55(0.24-1.29)$ & - & $0.70(0.30-1.63)$ & - & $0.73(0.42-1.27)$ & - & $0.62(0.28-1.38)$ & - & $0.76(0.51-1.12)$ & - \\
\hline \multicolumn{13}{|c|}{ Source of control } \\
\hline $\mathrm{PB}$ & 12 & $2386 / 5406$ & $1.08(0.86-1.36)$ & 0.306 & $1.18(0.98-1.41)$ & 0.006 & $1.03(0.86-1.25)$ & 0.200 & $1.15(0.98-1.34)$ & 0.030 & $1.09(0.99-1.19)$ & 0.262 \\
\hline $\mathrm{HB}$ & 11 & $872 / 1423$ & $1.06(0.61-1.84)$ & 0.004 & $1.05(0.71-1.55)$ & $<0.001$ & $1.08(0.83-1.40)$ & 0.135 & $1.03(0.67-1.57)$ & $<0.001$ & $1.02(0.75-1.39)$ & $<0.001$ \\
\hline \multicolumn{13}{|c|}{ Quality score } \\
\hline$\geq 9$ & 15 & $2835 / 5975$ & $1.13(0.88-1.47)$ & 0.054 & $1.19(0.98-1.44)$ & $<0.001$ & $1.11(0.94-1.32)$ & 0.124 & $1.17(0.98-1.41)$ & $<0.001$ & $1.11(0.98-1.25)$ & 0.002 \\
\hline$<9$ & 9 & $436 / 867$ & $0.77(0.39-1.49)$ & 0.064 & $0.98(0.63-1.50)$ & 0.033 & $0.81(0.56-1.16)$ & 0.425 & $0.91(0.56-1.47)$ & 0.004 & $0.91(0.64-1.29)$ & 0.002 \\
\hline
\end{tabular}

Het, heterogeneity; OR, odds ratio; CI, confidence interval; HB, hospital based; PB, population based.

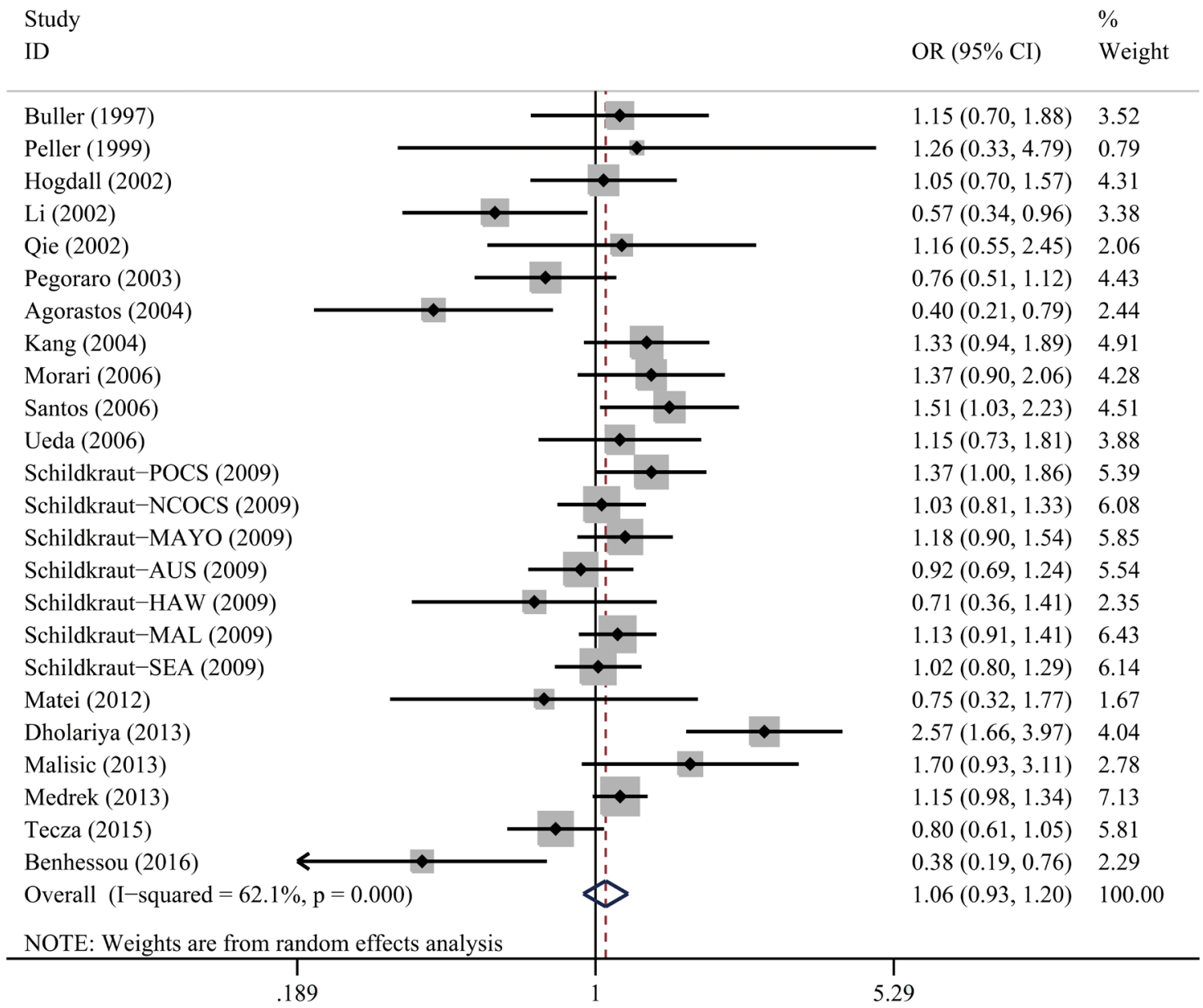

Figure 2: Forest plot for TP53 Arg72Pro polymorphism and ovarian cancer risk by allele comparison model. For each study, the estimation of OR and $95 \% \mathrm{CI}$ were plotted with a box and a horizontal line. The symbol filled diamond indicates pooled OR and $95 \%$ CI. 


\section{Heterogeneity and sensitivity analyses}

As shown in Table 2, significant heterogeneities were observed among studies in the homozygous $(P=$ $0.015)$, heterozygous $(P<0.001)$, recessive $(P=0.131)$ and dominant $(P<0.001)$ models, as well as with allele comparing $(P<0.001)$. We adopted the random-effects model to solve the significant heterogeneity between studies, because it generated wider CIs to estimate genetic susceptibility. To confirm the impact of each study on summary ORs, sensitivity analysis was conducted by separately omitting each single study involved in the analysis and recalculating ORs and the 95\% CIs. This analysis showed our results to be statistically robust, as the corresponding pooled ORs and 95\% CIs were not materially changed by any of the omissions (data not shown).

\section{Publication bias}

In this meta-analysis, publication bias was assessed using Begg's and Egger's tests (Figure 3). The results demonstrated that there was no potential publication bias present in the included articles under three genetic models (heterozygous: $P=0.945$; dominant model: $P=0.752$ and allele comparing model: $P=0.371)$. However, it was important to note that obvious bias existed in the other two models (homozygous: $P=0.027$ and recessive model: $P=$ 0.032 ). The reason for the bias may be related to the small sample size so that no single study was considered to be the cause of the publication bias.

\section{DISCUSSION}

The tumor-suppressor protein p53 is a well-known deterrent to cell growth, which inhibits tumorigenesis by activating apoptotic machinery [37]. TP53 Arg72Pro, a common TP53 polymorphism, induces certain conformational p53 mutants and binds stably to another tumor suppressor, p73 $[38,39]$. The two polymorphic variants of TP53 exert different biochemical and biological effects on cell cycle progression. The Arg72 form induces higher levels of apoptosis than the Pro72 form, while the Pro72 form has the ability to induce growth arrest during the G1 phase of the cell cycle [40]. We therefore hypothesized that TP53 Arg72Pro polymorphism may be closely related to the risk of ovarian cancer. Although numerous studies have investigated the relationship between the TP53 Arg72Pro polymorphism and ovarian cancer risk, the results have been inconsistent. Hence, the current meta-analysis of 24 studies was employed further investigate the association between TP53 Arg72Pro polymorphism and ovarian cancer, which is the most comprehensive analysis to date. The overall pooled results suggest there is no significant connection between the TP53 Arg72Pro polymorphism and ovarian cancer risk in five genetic models. This result was further confirmed in analyses stratified based on

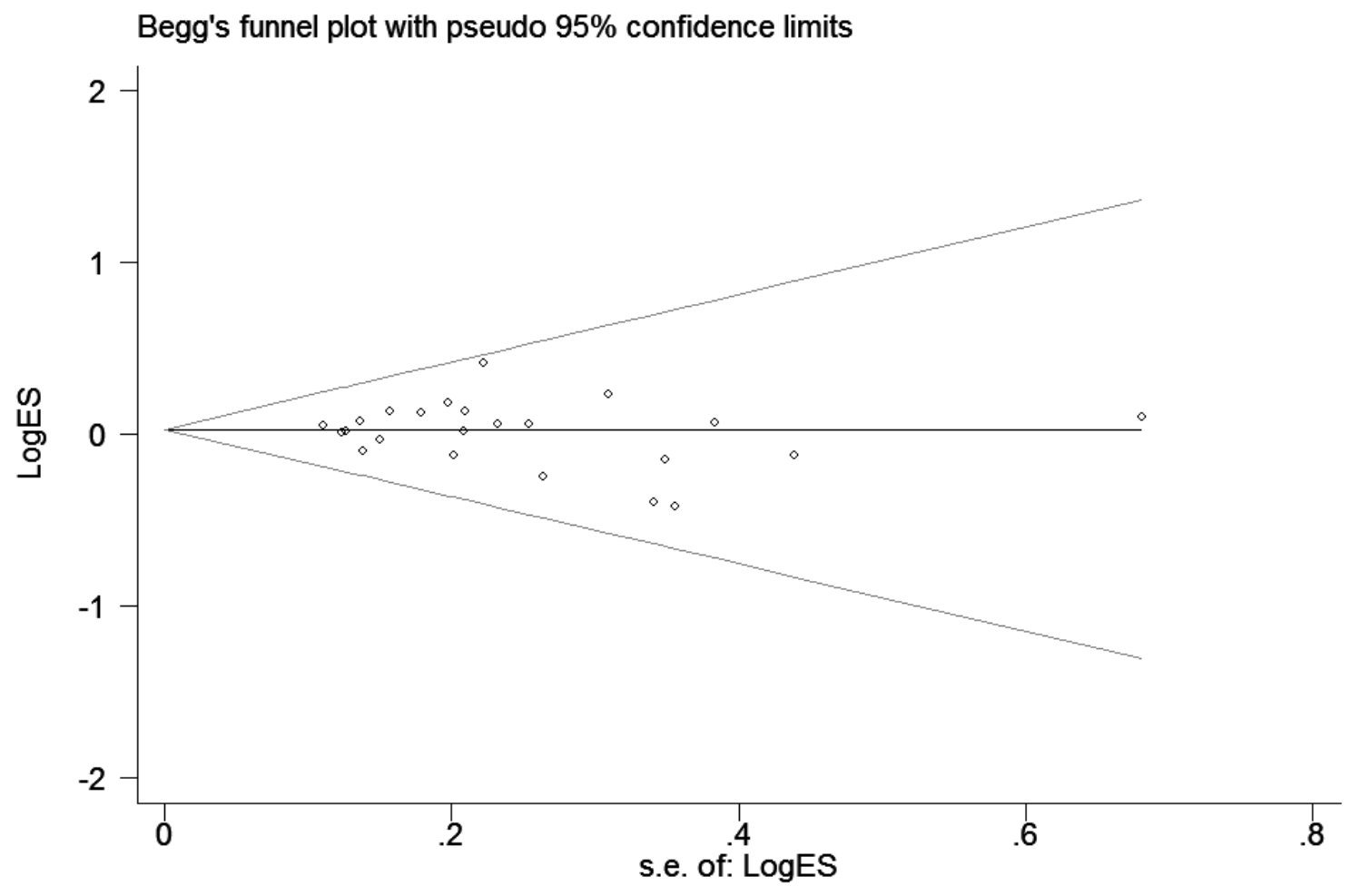

Figure 3: Funnel plot analysis to detect publication bias for TP53 Arg72Pro polymorphism under allele model. Each point represents a separate study for the indicated association. 
ethnicity, source of control and quality score. Consistent with the results of present meta-analysis, some earlier studies found that there is little or no association between TP53 Arg72Pro polymorphism and ovarian cancer risk. Likewise, an previous meta-analysis conducted by Francisco et al. [41] detected no association between the TP53 Arg72Pro polymorphism and ovarian cancer risk under any genetic model, and stratified analyses also failed to validate a genetic association. On the other hand, a study by Shen et al. [42] concluded that the TP53 Arg72 allele was associated with a modest, but significantly reduced risk of ovarian cancer when the included studies were classified as high quality. In yet another analysis, the main findings of 19 case-control studies, including 2,240 cases and 5,246 controls, were similar to those of the present study, though the subgroup analysis indicated a marginal association between the TP53 Arg72Pro polymorphism and ovarian cancer risk in the heterozygote model in Caucasians [43].

One possible explanation for why it is difficult to detect an effect of TP53 codon 72 polymorphism on ovarian cancer based on these epidemiological results is that there was loss of heterozygosity $(\mathrm{LOH})$ at the TP53 locus. Based on the previous publications, the TP53 Arg allele is preferentially mutated and expressed, while the Pro allele is lost in TP53 Arg72/ Pro72 heterozygotes across several cancer types [44, 45]. Thus the results of these genetic association studies may be biased by preferential LOH of the Pro allele. In addition, the results were probably influenced by individual infections with tumor-associated human papillomaviruses (HPVs). Storey found that the Arg 72 isoform was more susceptible to degradation by E6 protein of HPV16 than Pro 72 isoform in a heterozygous situation [46]. However, the original data on HPV infection were unavailable from the included studies, so further stratified analysis based on HPV infection status was not done.

The merits of the present meta-analysis in the context of the previously published ones are as follows. (a) We used an expanded retrieval range that included the latest studies and minimized selection bias. (b) There was a larger sample size and greater statistical power. (c) Our study is further verification that the TP53 Arg72Pro polymorphism has no impact on ovarian cancer risk. Nonetheless, there are still several limitations to the present meta-analysis. First, the sample sizes of many of the included studies were small, which contributed to reducing the statistical power of the genetic association estimate. Second, this meta-analysis only included publications in English and Chinese, which could lead to selection bias. Third, there were three studies in which the detected genotype frequencies deviated from the HWE [26, 31], making biased results inevitable. Fourth, significant heterogeneity was present under four genetic models, which may be attributable to ethnic differences and/or variation in sample size, study design or genotyping methods. Fifth, the well-known protective factors for ovarian cancer, such as bearing children, oral contraceptives and breastfeeding, were not taken into account due to a lack of individual information. Finally, we did not consider the possibility of the gene-gene interaction.

Despite of these limitations, the pooled results demonstrated that there was no significant association between the TP53 Arg72Pro polymorphism and ovarian cancer risk. Future well-designed studies that include large samples and take environmental factors into account will be necessary to validate our findings.

\section{MATERIALS AND METHODS}

\section{Identification of relevant studies}

We conducted a search of the PubMed, EMBASE and Chinese Biomedical (CBM) databases using the following keywords: "TP53 or p53", "polymorphism or variant or variation" and "ovarian" (prior to May 1, 2017). In addition, the references lists of the original articles and reviews were checked manually to identify additional studies. For overlapping data and republished studies, only the latest and largest studies were included in the current meta-analysis.

\section{Inclusion and exclusion criteria}

Inclusion criteria for studies were as follows: (a) evaluation of the association between the TP53 gene Arg72Pro polymorphism and ovarian cancer risk, (b) casecontrol design, (c) sufficient and adequate data provided to calculate crude OR and 95\% CI, (d) the data were reported in English or Chinese.

Studies were excluded for the following reasons: (a) duplicate publication, (b) cases only studies, or (c) article was a review, case report, editorial or expert opinion.

\section{Data extraction}

Two reviewers (Anqi Zhang and Jing He) assessed weather the retrieved studies met the inclusion criteria, and extracted data from each eligible study. If the two reviewers did not separately reach a unanimous decision on any one item, the dispute was resolved by joint review and consensus. The information retrieved from each study was as follows: the first author's surname, publication data, country of origin, ethnicity, source of control, total number of cases and controls, genotype methods, and numbers of cases and controls for the TP53 Arg72Pro. Based on differently stratified analyses, ethnicity was divided into three categories: Asians, Caucasians and Africans, and controls were divided into hospital-based and population-based. 


\section{Statistical methods}

The strength of the association between TP53 Arg72Pro polymorphism and ovarian cancer susceptibility was recalculated using crude ORs with the corresponding 95\% CIs. The pooled ORs were calculated for the homozygous (Pro/Pro vs. Arg/Arg), heterozygous (Arg/ Pro vs. Arg/Arg), dominant [(Arg/Pro + Pro/Pro) vs. Arg/Arg], and recessive [Pro/Pro vs. (Arg/Pro + Arg/ Arg)] models, as well as allele comparison (Pro vs. Arg). The Chi square-based Q test was used to calculate the heterogeneity between studies. If the $P$ value was less than 0.1 , the pooled ORs were calculated using a randomeffects model (the DerSimonian and Laird method) [47]. Otherwise, a fixed-effect model (the Mantel-Haenszel method) was chosen for further calculation [48]. Subgroup analyses were classified into three parts: ethnicity, study design and quality score. The quality score for each study was assessed in accordance with the evaluation criteria, as described previously [49-51]. The quality scores ranged from 0 to 15 , with scores $\geq 9$ defined as high quality, while $<9$ were defined as low quality. Publication bias was assessed by constructing a funnel plots, after which the asymmetry of the funnel plots was assessed using Egger's linear regression test [52]. HWE was evaluated using the chi-square-based Q-test, values of $P<0.05$ were regarded as deviations from the HWE. All statistical tests were conducted using STATA software (version 11.0; Stata Corporation, College Station, TX). Values of $P<0.05$ was considered significant, and all tests were two-sided.

\section{ACKNOWLEDGMENTS}

This study was supported by grants from the Natural Science Foundation of Zhejiang Provincial (LY16H160054, LY16040011, and Y16H160214), the Public Welfare Science and Technology Project of Wenzhou City (Y20150044), and National Natural Science Foundation of China (81401184).

\section{CONFLICTS OF INTEREST}

The authors declare no competing financial interests.

\section{REFERENCES}

1. Torre LA, Bray F, Siegel RL, Ferlay J, Lortet-Tieulent J, Jemal A. Global cancer statistics, 2012. CA Cancer J Clin. 2015; 65:87-108. https://doi.org/10.3322/caac.21262.

2. Modugno F, and Ovarian Cancer and High-Risk Women Symposium Presenters. Ovarian cancer and high-risk women-implications for prevention, screening, and early detection. Gynecol Oncol. 2003; 91:15-31. https://doi. org/10.1016/S0090-8258(03)00254-3.

3. Siegel R, Ward E, Brawley O, Jemal A. Cancer statistics, 2011: the impact of eliminating socioeconomic and racial disparities on premature cancer deaths. CA Cancer J Clin. 2011; 61:212-36. https://doi.org/10.3322/caac.20121.

4. Nunns D, Symonds P, Ireland D. Surgical management of advanced ovarian cancer. Obstet Gynecol Surv. 2000; 55:74651. https://doi.org/10.1097/00006254-200012000-00005.

5. Chan JK, Kapp DS, Shin JY, Husain A, Teng NN, Berek JS, Osann K, Leiserowitz GS, Cress RD, O'Malley C. Influence of the gynecologic oncologist on the survival of ovarian cancer patients. Obstet Gynecol. 2007; 109:134250. https://doi.org/10.1097/01.AOG.0000265207.27755.28.

6. Vineis P, Perera F. Molecular epidemiology and biomarkers in etiologic cancer research: the new in light of the old. Cancer Epidemiol Biomarkers Prev. 2007; 16:1954-65. https://doi.org/10.1158/1055-9965.EPI-07-0457.

7. Mok SC, Kwong J, Welch WR, Samimi G, Ozbun L, Bonome T, Birrer MJ, Berkowitz RS, Wong KK. Etiology and pathogenesis of epithelial ovarian cancer. Dis Markers. 2007; 23:367-76. https://doi.org/10.1155/2007/474320.

8. Walker KK, Levine AJ. Identification of a novel p53 functional domain that is necessary for efficient growth suppression. Proc Natl Acad Sci USA. 1996; 93:15335-40. https://doi.org/10.1073/pnas.93.26.15335.

9. Levine AJ, Finlay CA, Hinds PW. P53 is a tumor suppressor gene. Cell. 2004 (Suppl); 116:S67-69. https://doi. org/10.1016/S0092-8674(04)00036-4.

10. Vogelstein B, Kinzler KW. Cancer genes and the pathways they control. Nat Med. 2004; 10:789-99. https://doi. org/10.1038/nm1087.

11. Malkin D, Li FP, Strong LC, Fraumeni JF Jr, Nelson CE, Kim DH, Kassel J, Gryka MA, Bischoff FZ, Tainsky MA, Friend SH. Germ line p53 mutations in a familial syndrome of breast cancer, sarcomas, and other neoplasms. Science. 1990; 250:1233-38. https://doi.org/10.1126/ science. 1978757.

12. Whibley C, Pharoah PD, Hollstein M. p53 polymorphisms: cancer implications. Nat Rev Cancer. 2009; 9:95-107. https://doi.org/10.1038/nrc2584.

13. Wang Y, Wu XS, He J, Ma T, Lei W, Shen ZY. A novel TP53 variant (rs78378222 A $>$ C) in the polyadenylation signal is associated with increased cancer susceptibility: evidence from a meta-analysis. Oncotarget. 2016; 7:3285465. https://doi.org/10.18632/oncotarget.9056.

14. Li J, Zou L, Zhou Y, Li L, Zhu Y, Yang Y, Gong Y, Lou J, Ke J, Zhang Y, Tian J, Zou D, Peng X, et al. A lowfrequency variant in SMAD7 modulates TGF- $\beta$ signaling and confers risk for colorectal cancer in Chinese population. Mol Carcinog. 2017; 56:1798-807. https://doi. org $/ 10.1002 / \mathrm{mc} .22637$.

15. Lou J, Gong J, Ke J, Tian J, Zhang Y, Li J, Yang Y, Zhu Y, Gong Y, Li L, Chang J, Zhong R, Miao X. A functional polymorphism located at transcription factor binding sites, rs6695837 near LAMC1 gene, confers risk of colorectal cancer in Chinese populations. Carcinogenesis. 2017; $38: 177-83$. 
16. Ara S, Lee PS, Hansen MF, Saya H. Codon 72 polymorphism of the TP53 gene. Nucleic Acids Res. 1990; 18:4961. https:// doi.org/10.1093/nar/18.16.4961.

17. Harris N, Brill E, Shohat O, Prokocimer M, Wolf D, Arai $\mathrm{N}$, Rotter V. Molecular basis for heterogeneity of the human p53 protein. Mol Cell Biol. 1986; 6:4650-56. https://doi. org/10.1128/MCB.6.12.4650.

18. Thomas M, Kalita A, Labrecque S, Pim D, Banks L, Matlashewski G. Two polymorphic variants of wildtype p53 differ biochemically and biologically. Mol Cell Biol. 1999; 19:1092-100. https://doi.org/10.1128/ MCB.19.2.1092.

19. Li T, Lu ZM, Guo M, Wu QJ, Chen KN, Xing HP, Mei Q, Ke Y. p53 codon 72 polymorphism $(\mathrm{C} / \mathrm{G})$ and the risk of human papillomavirus-associated carcinomas in China. Cancer. 2002; 95:2571-76. https://doi.org/10.1002/ cncr.11008.

20. Agorastos T, Masouridou S, Lambropoulos AF, Chrisafi S, Miliaras D, Pantazis K, Constantinides TC, Kotsis A, Bontis I. P53 codon 72 polymorphism and correlation with ovarian and endometrial cancer in Greek women. Eur J Cancer Prev. 2004; 13:277-80. https://doi.org/10.1097/01. cej.0000136717.95465.09.

21. Benhessou M, Assoumou S, Boumba L, Bouhya $\mathrm{S}$, Benchekroun M, Ennaji M. The p53 Codon 72 Polymorphism in Moroccan Women and the Risk of Ovarian Cancer. Br Microbiol Res J. 2016; 12:1-5. https:// doi.org/10.9734/BMRJ/2016/22295.

22. Dholariya S, Zuberi M, Ray PC, Gandhi G, Khurana N, Yadav P, Mohapatra S, Javid J, Ahamad I, Saxena A, Mir R. TP53 Gene Polymorphism in Epithelial Ovarian Carcinoma Patients from North Indian Population and its Pro/Pro Variant is Potentially Contributing to Cancer Susceptibility. J Genet Syndr Gene Ther. 2013; 4:145.

23. Santos AM, Sousa H, Pinto D, Portela C, Pereira D, Catarino R, Duarte I, Lopes C, Medeiros R. Linking TP53 codon 72 and P21 nt590 genotypes to the development of cervical and ovarian cancer. Eur J Cancer. 2006; 42:958-63. https://doi. org/10.1016/j.ejca.2006.01.015.

24. Malisic EJ, Jankovic RN, Jakovljevic KV, Radulovic SS. Association of TP53 codon 72 polymorphism with susceptibility to ovarian carcinomas in Serbian women. Eur J Obstet Gynecol Reprod Biol. 2013; 166:90-93. https://doi. org/10.1016/j.ejogrb.2012.10.002.

25. Høgdall EV, Høgdall CK, Christensen L, Glud E, Blaakaer J, Bock JE, Vuust J, Nørgaard-Pedersen B, Kjaer SK. Distribution of p53 codon 72 polymorphisms in ovarian tumour patients and their prognostic significance in ovarian cancer patients. Anticancer Res. 2002; 22:1859-64.

26. Schildkraut JM, Goode EL, Clyde MA, Iversen ES, Moorman PG, Berchuck A, Marks JR, Lissowska J, Brinton L, Peplonska B, Cunningham JM, Vierkant RA, Rider DN, et al, and Australian Ovarian Cancer Study Group. Single nucleotide polymorphisms in the TP53 region and susceptibility to invasive epithelial ovarian cancer. Cancer Res. 2009; 69:2349-57. https://doi.org/10.1158/0008-5472. CAN-08-2902.

27. Qie M, Zhang Y, Wu J. Study on the relationship between cervical cancer and p53 codon 72 polymorphism. [Article in Chinese] Hua Xi Yi Ke Da Xue Xue Bao. 2002; 33:274-75.

28. Pegoraro RJ, Moodley M, Rom L, Chetty R, Moodley J. P53 codon 72 polymorphism and BRCA 1 and 2 mutations in ovarian epithelial malignancies in black South Africans. Int J Gynecol Cancer. 2003; 13:444-49. https://doi. org/10.1046/j.1525-1438.2003.13333.x.

29. Kang S, Duan LH, Zhang JH, Guo W, Wang N, Li Y. Association of p53 gene polymorphism with susceptibility to ovarian cancer. [Article in Chinese] Zhonghua Fu Chan Ke Za Zhi. 2004; 39:754-58.

30. Morari EC, Lima AB, Bufalo NE, Leite JL, Granja F, Ward LS. Role of glutathione-S-transferase and codon 72 of P53 genotypes in epithelial ovarian cancer patients. J Cancer Res Clin Oncol. 2006; 132:521-28. https://doi.org/10.1007/ s00432-006-0099-3.

31. Ueda M, Terai Y, Kanda K, Kanemura M, Takehara M, Yamaguchi H, Nishiyama K, Yasuda M, Ueki M. Germline polymorphism of $\mathrm{p} 53$ codon 72 in gynecological cancer. Gynecol Oncol. 2006; 100:173-78. https://doi. org/10.1016/j.ygyno.2005.08.015.

32. Matei MC, Negură L, Liliac L, Negură A, Azoicăi D. Validation of PCR-RFLP techniques for the evaluation of codon 72 of p53 and CYP1A1 gene's polymorphisms in relation with ovarian cancer in a Romanian population. Rom J Morphol Embryol. 2012; 53:47-54.

33. Mędrek K, Magnowski P, Masojć B, Chudecka-Głaz A, Torbe B, Menkiszak J, Spaczyński M, Gronwald J, Lubiński J, Górski B. Association of common WRAP 53 variant with ovarian cancer risk in the Polish population. Mol Biol Rep. 2013; 40:2145-47. https://doi.org/10.1007/ s11033-012-2273-9.

34. Tecza K, Pamula-Pilat J, Kolosza Z, Radlak N, Grzybowska E. Genetic polymorphisms and gene-dosage effect in ovarian cancer risk and response to paclitaxel/cisplatin chemotherapy. J Exp Clin Cancer Res. 2015; 34:2. https:// doi.org/10.1186/s13046-015-0124-y.

35. Buller RE, Sood A, Fullenkamp C, Sorosky J, Powills $\mathrm{K}$, Anderson B. The influence of the p53 codon 72 polymorphism on ovarian carcinogenesis and prognosis. Cancer Gene Ther. 1997; 4:239-45.

36. Peller S, Halperin R, Schneider D, Kopilova Y, Rotter V. Polymorphisms of the p53 gene in women with ovarian or endometrial carcinoma. Oncol Rep. 1999; 6:193-97.

37. Levine A, Finlay C, Hinds P. P53 is a tumor suppressor gene. Cell. 2004; 116:S67-69, 61. https://doi.org/10.1016/ S0092-8674(04)00036-4.

38. Vousden KH, Lu X. Live or let die: the cell's response to p53. Nat Rev Cancer. 2002; 2:594-604. https://doi. org/10.1038/nrc864. 
39. Tada M, Furuuchi K, Kaneda M, Matsumoto J, Takahashi M, Hirai A, Mitsumoto Y, Iggo RD, Moriuchi T. Inactivate the remaining $\mathrm{p} 53$ allele or the alternate $\mathrm{p} 73$ ? Preferential selection of the Arg72 polymorphism in cancers with recessive p53 mutants but not transdominant mutants. Carcinogenesis. 2001; 22:515-17. https://doi.org/10.1093/ carcin/22.3.515.

40. Pim D, Banks L. p53 polymorphic variants at codon 72 exert different effects on cell cycle progression. Int J Cancer. 2004; 108:196-99. https://doi.org/10.1002/ijc.11548.

41. Francisco G, Menezes PR, Eluf-Neto J, Chammas R. Arg72Pro TP53 polymorphism and cancer susceptibility: a comprehensive meta-analysis of 302 case-control studies. Int J Cancer. 2011; 129:920-30. https://doi.org/10.1002/ ijc. 25710 .

42. Shen SQ, Jiang DK, Liu GY, Chen F, Yu L. Meta-analysis shows significant association of the TP53 Arg72Pro with ovarian cancer risk. Mol Biol Rep. 2012; 39:4683-90. https://doi.org/10.1007/s11033-011-1260-x.

43. Xi Y, Liu C, Xin X. Association between a single nucleotide polymorphism in the TP53 region and risk of ovarian cancer. Cell Biochem Biophys. 2014; 70:1907-12. https:// doi.org/10.1007/s12013-014-0150-y.

44. Marin MC, Jost CA, Brooks LA, Irwin MS, O’Nions J, Tidy JA, James N, McGregor JM, Harwood CA, Yulug IG, Vousden KH, Allday MJ, Gusterson B, et al. A common polymorphism acts as an intragenic modifier of mutant p53 behaviour. Nat Genet. 2000; 25:47-54. https://doi. org/10.1038/75586.

45. Schneider-Stock R, Boltze C, Peters B, Szibor R, Landt O, Meyer F, Roessner A. Selective loss of codon 72 proline p53 and frequent mutational inactivation of the retained arginine allele in colorectal cancer. Neoplasia. 2004; 6:52935. https://doi.org/10.1593/neo.04178.

46. Storey A, Thomas M, Kalita A, Harwood C, Gardiol D, Mantovani F, Breuer J, Leigh IM, Matlashewski G, Banks
L. Role of a p53 polymorphism in the development of human papillomavirus-associated cancer. Nature. 1998; 393:229-34. https://doi.org/10.1038/30400.

47. Mantel N, Haenszel W. Statistical aspects of the analysis of data from retrospective studies of disease. J Natl Cancer Inst. $1959 ; 22: 719-48$.

48. DerSimonian R, Laird N. Meta-analysis in clinical trials. Control Clin Trials. 1986; 7:177-88. https://doi. org/10.1016/0197-2456(86)90046-2.

49. Thakkinstian A, McKay GJ, McEvoy M, Chakravarthy U, Chakrabarti S, Silvestri G, Kaur I, Li X, Attia J. Systematic review and meta-analysis of the association between complement component 3 and age-related macular degeneration: a HuGE review and meta-analysis. Am J Epidemiol. 2011; 173:1365-79. https://doi.org/10.1093/ aje/kwr025.

50. He J, Liao XY, Zhu JH, Xue WQ, Shen GP, Huang SY, Chen W, Jia WH. Association of MTHFR C677T and A1298C polymorphisms with non-Hodgkin lymphoma susceptibility: evidence from a meta-analysis. Sci Rep. 2014; 4:6159. https://doi.org/10.1038/srep06159.

51. Xue WQ, He YQ, Zhu JH, Ma JQ, He J, Jia WH. Association of BRCA2 N372H polymorphism with cancer susceptibility: a comprehensive review and meta-analysis. Sci Rep. 2014; 4:6791. https://doi.org/10.1038/srep06791.

52. Egger M, Davey Smith G, Schneider M, Minder C. Bias in meta-analysis detected by a simple, graphical test. BMJ. 1997; 315:629-34. https://doi.org/10.1136/ bmj.315.7109.629. 